テレオ撮影が行われます。

\section{3. 脳血管造影}

脳血管障害および外傷性頭蓋内疾患において脳血管造 影が行われたものが39例ありました。その内訳はクモ膜 下出血28例, 脳出血 9 例, 脳梗塞および外傷性頭蓋内疾 患がそれぞれ 1 例でした。

クモ膜下出血の場合，原因としては脳動脈瘤の破裂， 脳動静脈奇形，モヤモヤ病，脳腫愓，血液疾患などが挙 げられ，出血の原因のほとんどは脳動脈瘤の破裂による ものだといわれ，当施設で過去に血管像を行われたクモ 膜下出血 470 例の内約 $90 \%$ 動脈瘤によるものでありま した ${ }^{1,2)}$. 動脈溜破裂によるクモ膜下出血は緊急手術の適 用となり，動脈瘤の確定診断，位置および形態診断のた めに緊急の血管造影が行われます。血管造影中に特に注 意すべきこととしては刺激などにより血圧が上昇して再 出血を起こす可能性がありますので検查中はできるだけ 刺激を与えないよう注意すべきです。

脳出血の場合, 高血圧性脳出血, 動静脈奇形, モヤモ ヤ病，腫瘍，血管炎，血液疾患などが挙げられますが， 緊急の外科的治療の対象となる皮質下出血で高血圧性脳 出血かそのほかの成因によるものかの鑑別, あるいは高 血圧性脳出血が疑いにくく，動静脈奇形やモヤモヤ病な どが疑われる場合，緊急のIVDSA が行われることがあ りますが，この場合，呼吸停止が得られませんので，造 影剤が頭部血管に達する一呼吸以上前から画像収拾を開 始しマスク像を呼吸の変動に合わせて変えてやると比較 的良い像が得られます．血管造影㳊関しては緊急に行わ れることは少なく，病態が安定してから行われますので 通常の脳血管造影と変わらないと思います。
脳血管障害や外傷性の頭蓋内疾患が疑われる患者さん は，いつ病態が悪化するか分からず，撮影にあたっては 呼吸状態に特に注意を要します。また撮影にあたって体 位移動を行った場合によく嘔吐されることがありますの で嘔吐に注意し嘔吐されそうな場合は体位を側臥位にし 顔を横向け，異物が気道に入らないように注意すべきで す.

救急医療の使命は救命であり救急医療のスタッフとし て働いているわれわれ放射線技師も救急法はマスターし， 患者さんが急変した場合に応用できるようにしておきた いものです.

\section{参考文献}

1）大川 渡，尾花恵子，草壁宏保，他：脳細胞増殖講 座，日放技師会誌 $438 ， 440 ， 441 ， 442 ４ 444 ， 445$

2）前原忠行：神経放射線診断，文光堂，東京， (1984)

3）鈴木明文：救急医学講座 脳血管障害, メジカルビ ュ一社, 東京

4）大塚俊文, 益子邦洋：救急医療の現況と展望 新医 療1990（8）

5）桂田菊嗣 意識障害：救急医学1989（10）

6）小林士郎，中沢省三：頭部外傷とその対応 救急医 学1989 (10)

7）澤田祐介他：救急医療に必要な画像診断，メジカル ビュー社, 東京，(1984)。

8）豊倉康夫他 神経内科学

9) Neuroanatomie der kraniellen Computertomographie Hans-Joachim Kretschmann \& Wolfgang Weinrich

\title{
4.おわりに
}

\section{4. 三次救急, 急性心筋梗塞について}

湯 田 逸 雄

社会保険小倉記念病院放射線科

\section{はじめに}

急性心筋梗塞 (acute myocardial infarction：AMI) そおける三次救急医療では，冠動脈造影（coronary an-
giography：CAG) が, 梗塞責任冠動脈の確定診断, 治療 法の決定，治療結果の判定に重要な役割を担う。より良 い情報をより多く術者に提供できるよう，当施設で行わ れている $\mathrm{CAG}$ 検査を主体に話題を提供したいと思う. 


\section{AMI ・ 三次救急医療}

AMI は, 冠動脈の急閉塞による冠血流の遮断により発 症し, その程度は冠閉塞部位（梗塞責任冠動脈の心筋栄 養範囲）と，その持続時間に影響される．急性冠閉塞の 主因は新鮮な血栓であることが証明されている，血栓の 成因は，冠動脈内根状硬化部の内膜破綻による冠動脈内 出血に伴う血栓形成や，冠スパズムによる一侍的冠血流 停止に伴う血栓形成などである.

AMI の三次救急医療としては, 速やかに冠血流を再開 させる再灌流療法（ウロキナーゼ：UK・組織プラスミ） ーゲンアクチベータ：t-PA などを投与する血栓溶解療 法・経皮的冠動脈形成術：PTCA）を施行することによ り，心筋壊死の進行を阻止し，梗塞部位の縮小，心機能 の保持，生存率の向上を図る事を目的とする，次に当施 設での，再灌流療法のガイドラインを示す.

\section{血栓溶解療法のガイドライン}

1. 心電図上明らかな ST 上昇を認めるもの

2. 持続する胸痛の出現後 6 時間以内

3. 75才以下

4. 収縮期血圧 $160 \mathrm{mmHg}$ 以下

5. 機械的合併症 (心室中隔穿孔，乳頭筋断裂，自由壁 破裂)，心原性ショックを合併していないこと

6. 背部痛, 大動脈閉鎖不全, 血圧左右差など解離性大 動脈瘤を疑わせる所見がないこと

7. 胃潰瘍など消化管出血の既往がないこと

8. 最近の頭部外傷, 既知の頭蓋内の新生物, 脳血管障 害の既往がないこと

9. 出血性素因がないこと

診断に疑問がある場合は血栓溶解療法を施行しない.

\section{PTCA 実施のガイドライン}

1. 心原性ショック (IABP下)

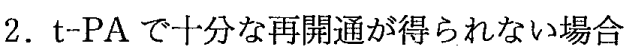

3. $\mathrm{t}-\mathrm{PA}$ 投与禁忌例

4. 発症後 6 時間以上を経過し, 胸痛が遷延もしくは $\mathrm{ST}$ 上昇が持続している

5. コントロール困難な高血圧

ただし,梗塞責任病変が PTCA の適合病変であることを 前提とする。

\section{救急体制}

循環器当直医

放射線技師（当直）

看護婦（当直）

梗塞当番医 (呼出) 1 名 1 名 2 名 2 名
臨床検查技師（呼出）

1 名 放射線技師に関しては，1週間ずつのトレーニングを 繰り返し実施している。

\section{2. 再灌流療法}

\section{1 血栓溶解療法}

- 経静脈的注入法

組織プラスミノーゲンアクチベータ（t-PA）を静脈内 投与する方法である.

特徵としては, $\mathrm{CAG}$ 設備の整っていない施設でも施行 できる（AMI 発症早期に治療を開始できる）ことであ る。ただし，静脈内投与後は，不整脈に気をつけて三次 救急医療施設へ搬送する。

問題点としては，再開通率がほかの方法に比べ低率(約 70\%) であること．大量の薬剤を使用しなければならな いため, 出血性の副作用が多いこと.CAG を施行しなけ れば，病態の完全な把握ができないことなどである。

- 選択的冠動脈内注入法（intra coronary thrombolysis : ICT)

$\mathrm{UK}$ - $\mathrm{t}-\mathrm{PA}$ を選択的に梗塞責任冠動脈内（右冠動脈, 左冠動脈）に投与する方法である.

特徴としては, 再開通率が経静脈法に比べ, $\mathrm{t}-\mathrm{PA}$ を使 用した場合約 $80 \%$ と高いこと.CAG を施行するので, 病 態の把握ができ治療効果もすぐに判定できることなどで ある.

問題点としては，CAG 設備の整った施設 (三次救急医 療施設）でスタッフが24時間体制をとらなければならな いこと. AMI 発症より治療開始までに時間がかかるこ と.診断 CAG より再開通までの時間がかかること.出血 性副作用があることなどである.

血栓溶解療法の問題点としては, AMI 発症より，6時 間以内での治療開始が原則となっていること．経皮的冠 動脈形成術に比べ再開通率が低いこと，再開通後，冠動 脈に高度な器質的狭窄が残存する場合には，冠動脈の再 閉塞（再梗塞）や梗塞後狭心症などの原因となりうるこ となどである。

\section{2 経皮的冠動脈形成術}

(percutaneous transluminal coronary angioplasty : PTCA)

拡張時, $1.5 \mathrm{~mm} \sim 4.0 \mathrm{~mm} \phi$ の Balloon catheter を Guiding catheter ・ Guide wireによって冠動脈内に導 き，冠閉塞（冠狭窄）部位にて Balloon を拡張させ，血 栓を破砕・圧排し，また残存狭窄を拡大する方法である.

- direct PTCA 
血栓溶解療法の禁忌患者などに, PTCA を直接施行す ることである.この方法の特徴としては, ほかの方法に 比べ再開通率が高い (約90\%). 診断 CAGより再開通ま での時間が ICT に比べ短い. 残存狭窄が少ないなどであ 万。

- rescue PTCA

血栓溶解療法が不成功に終わった場合や，成功しても 器質的残存狭窄が有意な場合（造影遅延が認められる場 合)，引き続きPTCA を施行することである．薬剤の影 響である拡張部位での出血や，残存血栓により，慢性期 の再閉塞率が direct PTCA に比べやや高率となる.

AMI 時の緊急 PTCA の問題点は, 待期的 PTCA に比 ベ, 急性冠再閉塞, distal embolism, 他枝への embolism がやや高率となること. 三次救急医療施設で, 熟練した スタッフが24時間体制をとらなければならないこと。術 者の技量により, 成功率, 合併症が左右されることなど である。

\section{3．当施設における，CAG 装置の改良 について}

S58年より.PTCA を開始するにあたり,家庭用21イン チモニタ・video disk recorder（VDR）などの周辺装置 を導入して良い結果を得ている. 装置・機器を改良し， 緊急時にも良い結果が得られている数例について述べる.

\subsection{X線管装置（島津製532J (750 KHU)， 0.6/1)}

Catheter・Guide wire・Balloon catheter などの医療

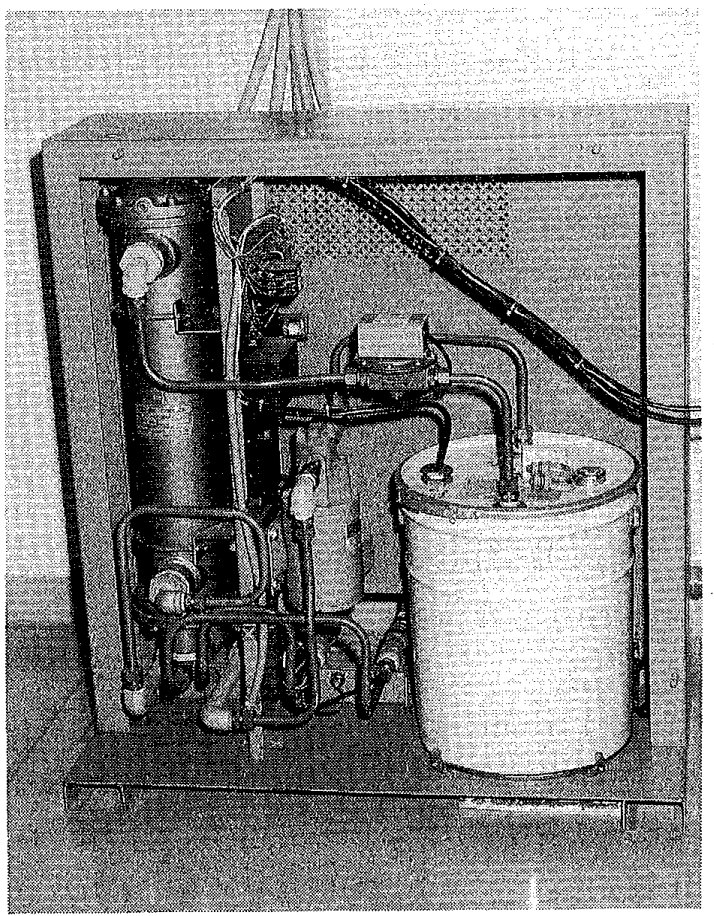

photo. 1-1 熱交換器本体
器具の進歩により一人あたりの検査所要時間が短縮され たことや(撮影インターバルの短縮)，1日に10～15件/室 の CAG，PTCAを施行しなければならないことにより (患者インターバルの短縮)，管装置の休止時間（管装置 の冷却時間) が短縮された。よって，X線管装置冷却率 を高くしなければ，サーマルスイッチが作動し15～20分 間検查を中断しなければならないようになった。

S 62年より熱交換器（島津製 HE 04：CT 用, photo. 1-1)を接続して良好な結果を得ている，この装置は，X

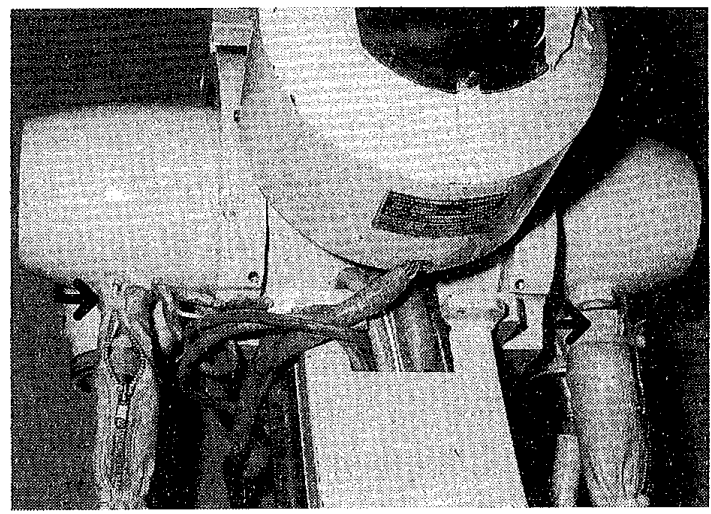

photo. 1-2 管装置接続部（矢印）

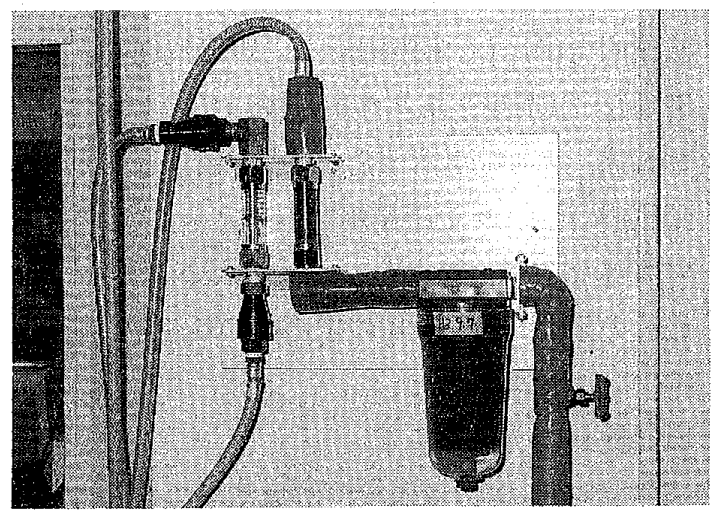

photo. 1-3 水量計 ・ 油量計

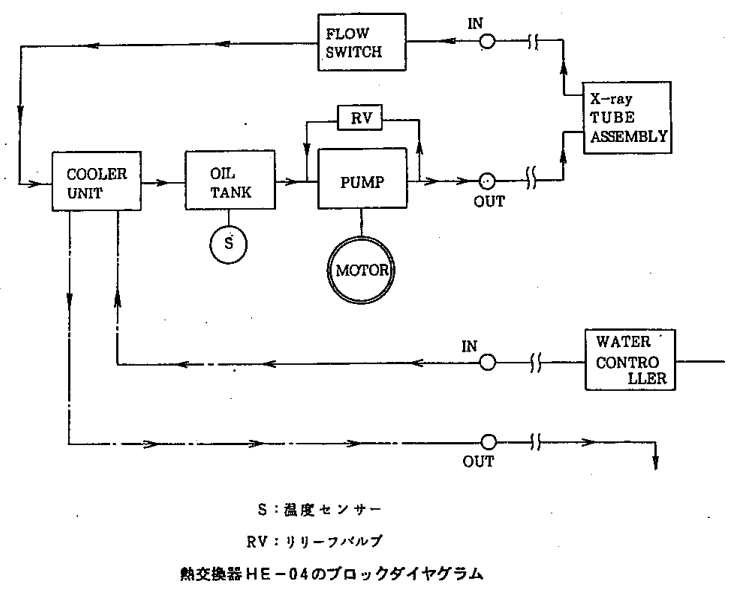

Fig. 1 
線管陽極を強制油冷する油循環形式のもので，冷却油は オイルクーラーユニットにより冷却(熱交換：水冷方式） される. photo. 1-2 に管装置接続部, photo. 1-3に水量 計, 油量計を, Fig. 1 に熱交換器ブロックダイヤグラムを 示す.

また，常に予備の管装置を準備しておくことにより， 不慮の故障に備えている.

\section{2 イメージインテンシファイア (以下 I.I., 島津製} IA-9VM)

9インチ視野 I.I. に扔いて通常は，9・7・6インチの 3 視野切り換えのところを，4インチ視野も加えて 4 視 野切り換えに改造した。この 4 インチ視野は, LMTや冠 動脈の特定病変部分だけをねらって撮影したい時や，緊

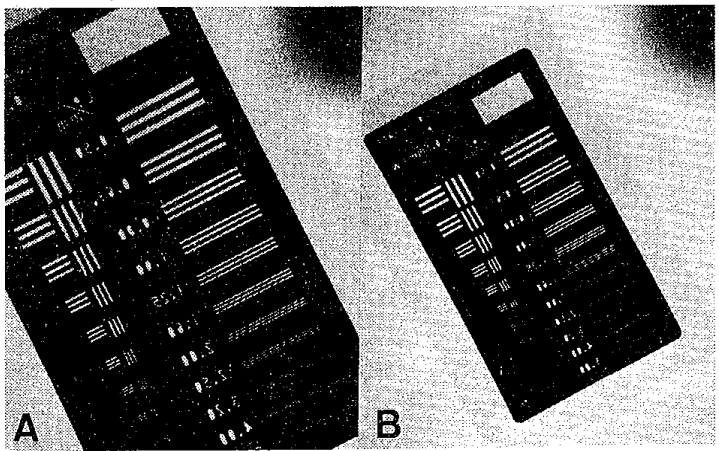

photo. 2-1 ピント調整時 (A：4インチ，B：6 インチ)

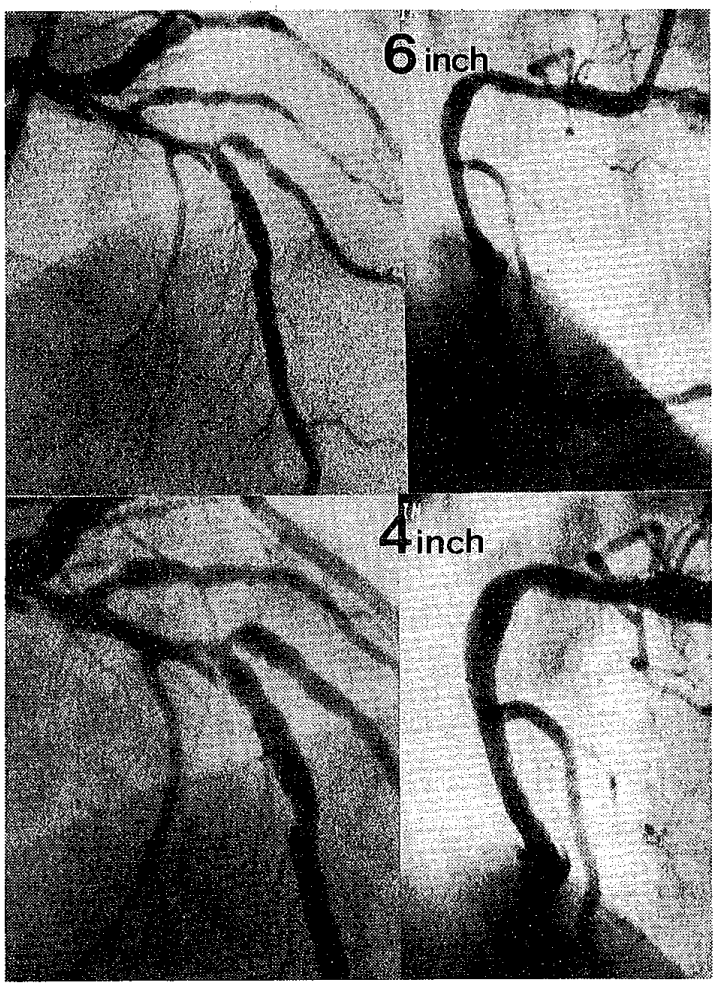

photo. 2-2 臨床例（上段：6インチ, 下段：4イ ンチ)
急時の治療結果の判定に有効である.（ただし，撮影条件 は高管電圧となる.）photo. 2-1にピント調整時のシネ 写真を, photo. 2-2 に, 臨床例を示す.

管理面では経時的に I.I.の相対的輝度を測定すること により，I.I.の劣化状態や交換時期を予測し，通常の $\mathrm{CAG}$ 検査や, 緊急 $\mathrm{CAG}$ 検查に支障を来さないようにし なければならない.

\section{3 分光器（島津製 OP-212）}

ミラー回転型（OP-311, photo. 3-1) の分光器では, シネカメラへの光軸と, 撮像管 (TVカメラ)への光軸が 一直線上に対向しているために，シネ撮影時にフィルム 面で反射した強い光が撮像管側にフィードバックされ， 虚像をモニ夕上に出現させる場合があった（Fig. 2-1）. この虚像は，あたかも側副血行路が存在するかのように 見えるため, モ二タ像で診断, 判定を行う AMI 緊急 CAGでは特に注意が必要であった。

対策として，メーカに虚像対策を施した分光器 (OP-

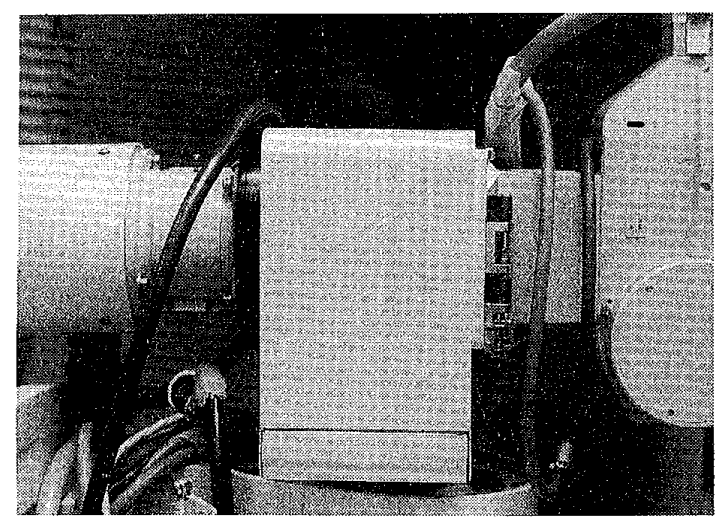

photo. 3-1 OP-311型分光器外観

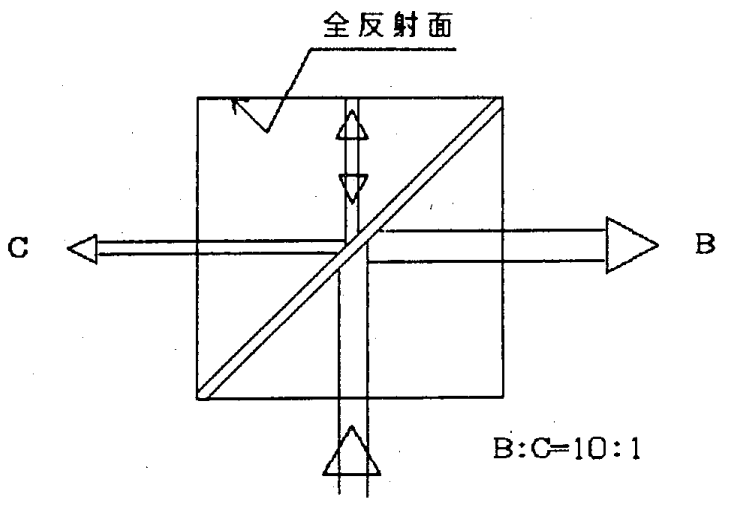

A

光量分割原理図

Fig. 2-1 OP-311型 




photo. 3-2 OP-212型分光器外観



A

$B: C=9: 1$

\section{光量分割原理図}

Fig. 2-2 OP-212型

212, photo. 3-2）の検討・作製を依頼した.この分光器 は, 両カメラへの光軸を上下にずらし, TV カメラへの反 射光がフィードバックしないように設計されている (Fig. 2-2).よって, 虚像が出現しない信頼度の高いモ二 夕像を得ることができた。そのほかの点で改良されたの は，透視時に分光用ミラーが I.I. 出力光軸より退避する ため, TVカメラへの光量が回転型分光器に比べ増した ことである.

\section{CAG 撮影に関して}

$\mathrm{H} 2$ 年 1 月 1 日より，H 3 年 10 月 23 日までの約 22 ケ 間における,総 $\mathrm{CAG}$ 件数は10822件であり, 緊急 $\mathrm{CAG}$ 件 数は551件である.その中で再灌流療法を施行したのは， 血栓溶解療法148例，PTCA 255例である。
緊急時は，心電図，心エコーなどの情報により，あら かじめ病態の把握をしておかなければならない.CAGで は，同一冠動脈を多方向から観察し各撮影方向での冠動 脈の走行を熟知しておかなければ，信頼度の高い診断， 治療ができない。また，患者様態急変時に備えたトレー ニングも必要である.

治療前には，梗塞責任冠動脈およびその断端がよく観 察される方向を数方向撮影する。また側副血行路の確認 もしなければならない. 治療後は, 治療結果の判定をし なければならないので，3〜 5 方向撮影する.

モニタ像で判断しなければならないため，ハレーショ ン防止に努めることが大切である。対策としては，フレ ーミング・パーンニング・ハレーション防止フィルタ （photo. 4）の操作などのトレーニングが必要である.



photo. 4 ハレーション防止フィルタ

まず, 左右冠動脈の各枝の名称 (Fig. 3-1) と AHA 分 類を示し(Fig. 3-2), 参考までに, 当施設での CAG 検査 における撮影方向を写真に示す（photo. 5-1，2，3）。

梗塞責任冠動脈の好発部位は, LAD seg. $6, \mathrm{LCx}$ seg. 11，RCA seg. 1 である.

seg. 6 の観察には, RAO caudal, caudal, cranial, RAO cranial LAO carnial, LAO caudal (Spider view)

seg. 11 の観察には, RAO caudal, caudal, LAO cra- 


\begin{tabular}{|c|c|}
\hline $\begin{array}{l}\text { RCA : right coronary artery (右冠動脈) } \\
\text { proximal seg. } 1 \\
\text { middle seg. } 2 \\
\text { distal seg. } 3 \\
\text { CN : conus artery } \\
\text { SN : sinus node artery } \\
\text { RV: right ventricular artery } \\
\text { AM : acute marginal artery } \\
\text { A : atrial artery } \\
\text { AV : AV node artery } \\
\text { PL : posterolateral artery seg. } 4 \\
\text { PD : posterior descending artery seg. } 4 \\
\text { S: septal branch }\end{array}$ & $\begin{array}{l}\text { LCA : left coronary artery (左冠動脈) } \\
\text { LMT: left main trunk seg. } 5 \\
\text { LAD : left anterior descending artery } \\
\text { proximal seg. } 6 \\
\text { middle seg. } 7 \\
\text { distal seg. } 8 \\
\text { D: diagonal artery } \\
\mathrm{D}_{1}: \text { first diagona! artery seg. } 9 \\
\mathrm{D}_{2}: \text { second diagonal artery seg. } 10 \\
\mathrm{~S}: \text { septal branch } \\
\text { CX: circumflex artery } \\
\text { proximal seg. } 11 \\
\text { distal seg. } 13 \\
\text { OM: obtuse marginal artery seg. } 12 \\
\text { PL: posterolateral artery seg. } 14 \\
\text { PD : posterior descending artery,seg. } 15 \\
\text { ACX : atrial circumflex artery seg. } 15 \\
\text { (SN: sinus node artery) } \\
\text { (AV: AV node artery) } \\
\text { A : atrial branch }\end{array}$ \\
\hline
\end{tabular}

Fig. 3-1 左右冠動脈の各枝の名称

左右冠斩暞の AHA 分期
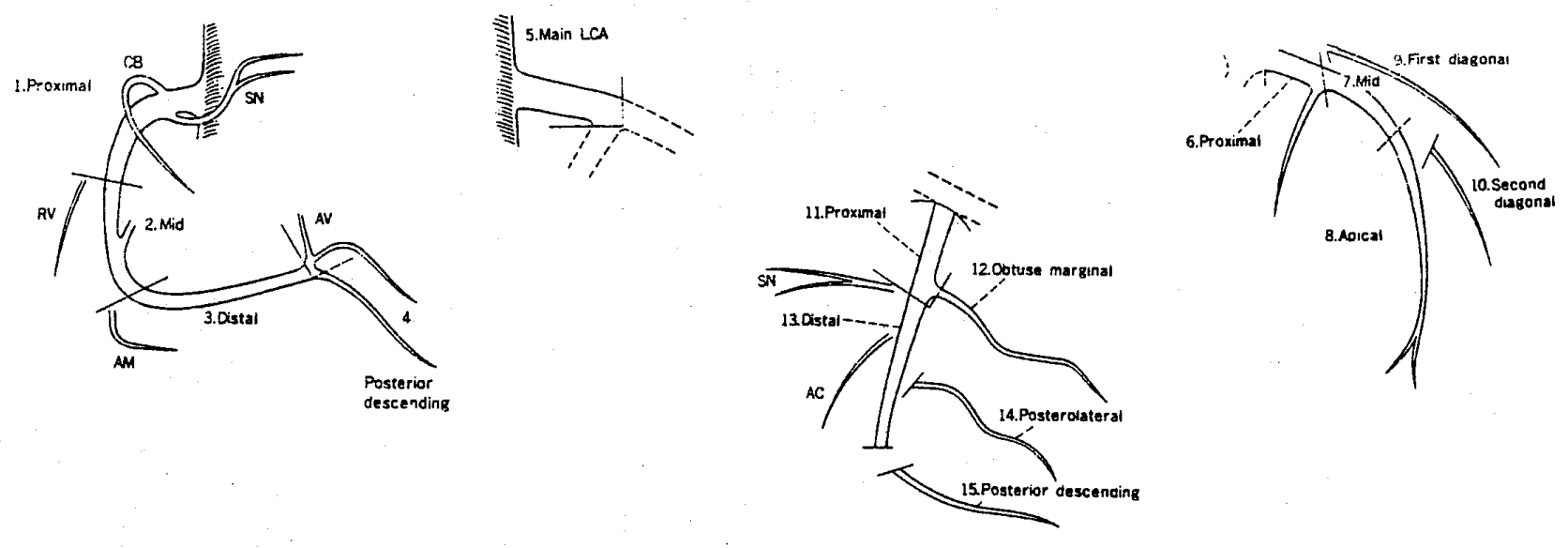

Fig. 3-2 AHA分類

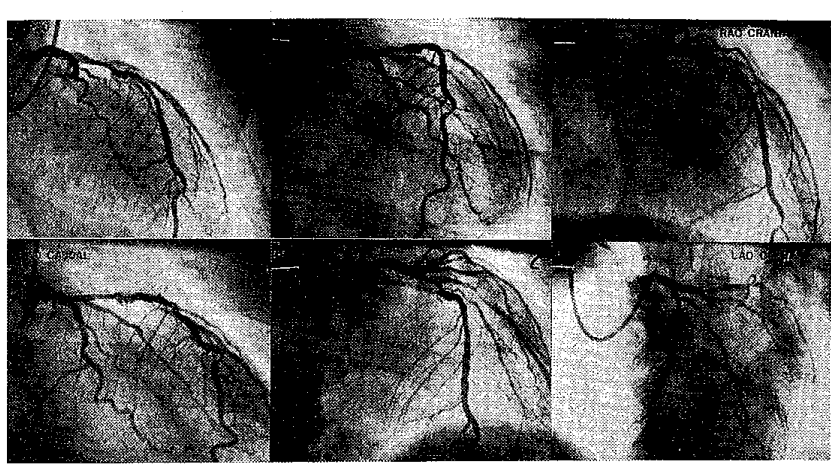

photo. 5-1 LCA各方向

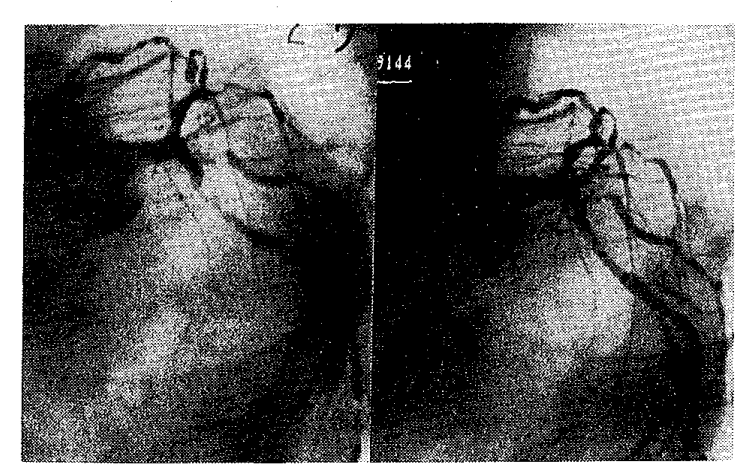

photo. 5-2 LCA LAO caudal 




photo. 5-3 RCA各方向

nial, LAO caudal

seg. 1 の観察には, LAO $60^{\circ}$, RAO $30^{\circ}$, LAO caudal RCA 末梢の観察には, cranial

の方向が適している.

左主幹部 (LMT) に病変がある場合は, LAO 15・4 亿 ンチ視野での撮影が適している（photo.6).

\section{5. 症例}

症例 1 は, 発症後 2 時間, 他医院より救急車にて搬送

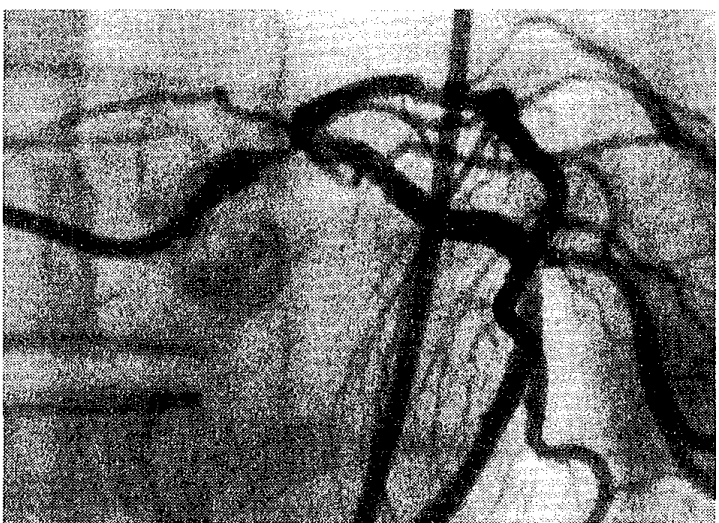

photo. 6 LMT LAO15・4 インチ

された患者である。カテ室入室時の心電眓では, 胸部誘 導 $V_{2} \sim V_{6} に て S T$ 上昇, 㕕範囲な前壁, 中隔, 側壁梗塞 が疑われた。 CAG 施行により，RCA seg. 1 は狭窄率75 \%, LAD seg. 6, LCx seg. 13 で完全閉塞が確認された (症例 1-1). 直ちに, 左冠動脈に ICT が施行され, 結果 は, LAD seg. 6 は狭窄率90\%で再開通を得た. LCx seg. 13 は, 造影遅延を伴う99\%狭窄率のため, rescue PTCA が施行され，良好な結果が得られた（症例 1-2）。

症例 2 は, 症例 1 の患者の翌日院内発症の例である. 心電図上, 肢誘導 $\mathrm{II} ・ \mathrm{III} \cdot \mathrm{a}_{\mathrm{F}}$ にて ST 上舁, 下壁梗塞が
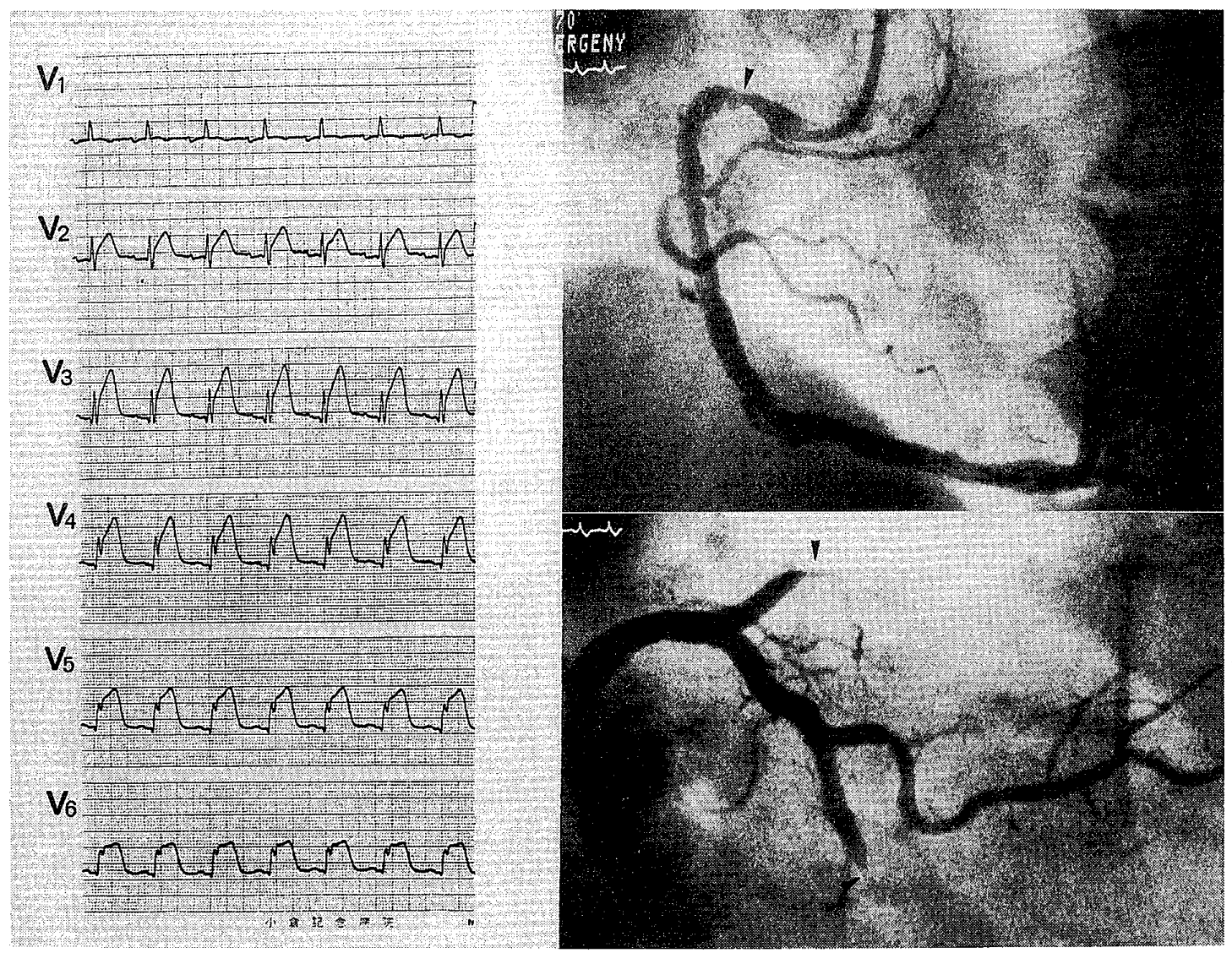

症例 $1-1$ 
〔放射線撮影分科会報告〕 4 . 三次救急，急性心筋梗塞について（湯田）



症例 1 - 2
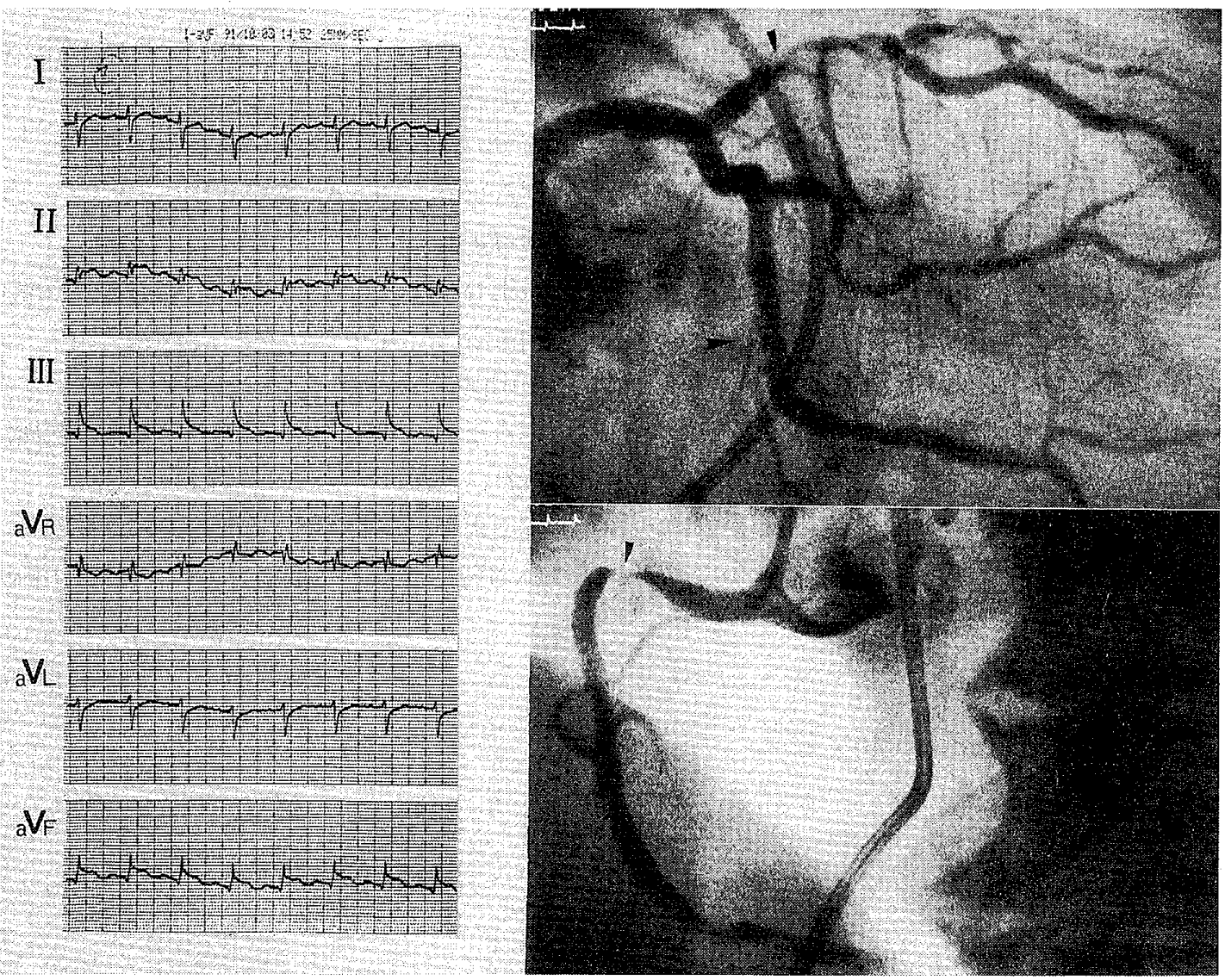

症例 $2-1$ 


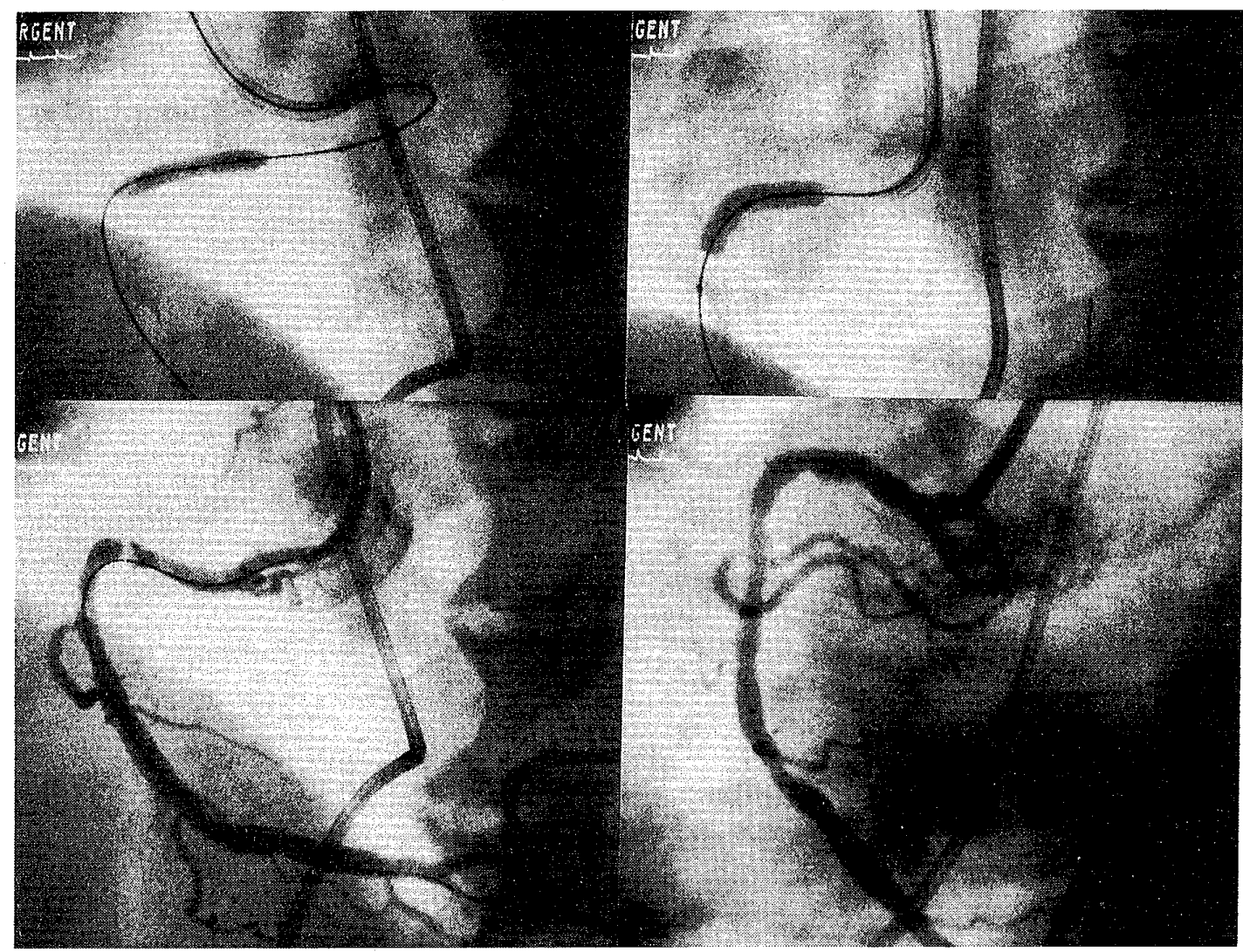

症例 2-2

疑われた。CAG 施行により，前日の治療箇所は良好な開 存が得られていた. RCA seg. 1 は造影遅延を伴う99\%狭 窄率に進行しており (症例 2-1), 直ちに, direct PTCA が施行されたが, dissectionが生じたため, PalmazSchatz STENT を implantation し，良好な結果を得た (症例 2-2).

\section{6.おわりに}

AMI に扔ける三次救急医療は，熟練したスタッフ・医 師・看護婦・臨床検查技師・放射線技師のチームワーク で行うべきである，その中で，放射線技師は重要な役割 を担っていることを，十分認識しておかなければならな い.また, 最近の $\mathrm{CAG}$ 装置は, DCI・大型高精細モ二タ・
大熱容量管装置・高 $\mathrm{Gx}$ 值・高解像度 I.I. など, めざまし い進歩であるが，さらに信頼度の高い，情報量の多い画 像を提供すべく努力しなければならない. なお，以下の文献を参考にしている. 延吉正清：PTCA，医学書院 延吉正清：新冠動脈造影法，医学書院 日本心血管形成術研究会編：急性心筋梗塞の PTCA, 三輪畫店

田中健藏：血栓症，メジカルビュー社

延吉正清・野坂秀行：PTCA の適応と限界, 現代医療 123(7), (1991).

細田瑳一・杉本恒明：心臟病学, 南江堂

INNER VISION 1990. 7，マグブロス出版株式会社 